\title{
Soluble tumour necrosis factor receptor type II and survival in colorectal cancer
}

\begin{abstract}
Ana Babic ${ }^{1,8}$, Sonali M Shah ${ }^{1,2,8}$, Mingyang Song ${ }^{3,4}$, Kana Wu$^{3}$, Jeffrey A Meyerhardt ${ }^{1}$, Shuji Ogino ${ }^{1,4,5}$, Chen Yuan ${ }^{1}$, Edward L Giovannucci ${ }^{3,4,6}$, Andrew T Chan ${ }^{6,7}$, Meir J Stampfer ${ }^{3,4,6}$, Charles S Fuchs ${ }^{1}$ and Kimmie Ng ${ }^{*, 1}$

${ }^{1}$ Department of Medical Oncology, Dana Farber Cancer Institute, Boston, MA 02215, USA; ${ }^{2}$ Division of Hematology and Oncology, Massachusetts General Hospital and Harvard Medical School, Boston, MA 02114, USA; ${ }^{3}$ Department of Nutrition, Harvard T. H. Chan School of Public Health, Boston, MA 02115, USA; ${ }^{4}$ Department of Epidemiology, Harvard T. H. School of Public Health, Boston, MA 02215, USA; ${ }^{5}$ Division of MPE Molecular Pathological Epidemiology, Department of Pathology, Brigham and Women's Hospital and Harvard Medical School, Boston, MA 02215, USA; ${ }^{6}$ Channing Division of Network Medicine, Department of Medicine, Harvard Medical School, Brigham and Women's Hospital, Boston, MA 02115, USA and 'Division of Gastroenterology, Massachusetts General Hospital and Harvard Medical School, Boston, MA 02114, USA
\end{abstract}

Background: Chronic inflammation may play a role in colorectal cancer (CRC) pathogenesis. The relationship between soluble tumour necrosis factor receptor type II (STNF-RII) and survival among CRC patients is not well defined.

Methods: We prospectively evaluated the association between pre-diagnosis plasma levels of sTNF-RII and mortality in 544 CRC patients from the Nurses' Health Study and Health Professionals Follow-Up Study diagnosed from 1990 to 2010. Primary and secondary end points were overall and CRC-specific mortality, respectively. Cox proportional hazards models were used to calculate multivariate hazard ratios for mortality.

Results: Higher sTNF-RIl levels were significantly associated with increased overall mortality (multivariate $\mathrm{HR}=1.48,95 \% \mathrm{Cl} 1.02-$ 2.16, $P$-trend $=0.006)$, but not with $C R C$-specific mortality $(H R=1.23,95 \% \mathrm{Cl} 0.72-2.08, P$-trend $=0.34)$. In subgroup analyses, among regular aspirin users, those with higher sTNF-RIl levels had an adjusted HR of 0.52 (95\% $\mathrm{Cl} 0.20-1.33$ ) for overall mortality compared with those with lower sTNF-RII levels, whereas among nonregular aspirin users the adjusted HR was $2.26(95 \% \mathrm{Cl} 1.23-$ 4.01, $P$ for interaction $=0.53$ ).

Conclusions: Among CRC patients, higher sTNF-RIl levels are associated with a significant increase in overall mortality, but not CRC-specific mortality. The role of inflammation and anti-inflammatory medications in survival of CRC patients warrants further exploration.

Chronic inflammation may play a role in the development and progression of colorectal cancer (CRC) (Bernstein et al, 2001; Kant and Hull, 2011; Song et al, 2013). Soluble tumour necrosis factor receptor type II (sTNF-RII; (HUGO Gene Nomenclature Committee (HGNC) ID TNFRSF1B) is the plasma form of the $75 \mathrm{kD}$ cell surface receptor for the pro-inflammatory cytokine tumour necrosis factor- $\alpha$ (TNF- $\alpha$ ) (Spoettl et al, 2007; Faustman and Davis, 2010). In CRC cells, TNF- $\alpha$ activates various inflammatory pathways and induces expression of cyclooxygenase-2 (COX-2), prostaglandin synthesis, increased tumour growth, and angiogenesis (Popivanova et al, 2008; Hamilton et al, 2011; Setia et al, 2013; Zhu et al, 2013). The TNF- $\alpha$ signalling is also associated with decreased apoptosis and chemotherapy resistance in metastatic CRC (Matsuyama et al, 2006).

Prospective observational studies have shown an association between sTNF-RII and increased risk of incident CRC in women (Chan et al, 2011). Multiple large randomised clinical trials have shown that inhibition of inflammation with medications such as

${ }^{*}$ Correspondence: $\mathrm{K} \mathrm{Ng}$; E-mail: kimmie_ng@dfci.harvard.edu

${ }^{8}$ These two authors contributed equally to this work.

Revised 3 March 2016; accepted 8 March 2016; published online 31 March 2016

(c) 2016 Cancer Research UK. All rights reserved 0007-0920/16 
aspirin and COX-2 (PTGS2) inhibitors can effectively prevent formation of colorectal adenomas in patients with a history of polyps or CRC (Steinbach et al, 2000; Sandler et al, 2003; Arber et al, 2006; Bertagnolli et al, 2006). Moreover, regular aspirin use has also been associated with improved survival in CRC patients (Chan et al, 2009). In contrast, the role of sTNF-RII in patients with established CRC is less clear. We therefore conducted a prospective study to investigate the association between levels of sTNF-RII and mortality in CRC patients from two large, wellestablished cohorts with over 20 years of follow-up data.

\section{MATERIALS AND METHODS}

Study population. Participants were drawn from the Nurses' Health Study (NHS) and Health Professionals Follow-Up Study (HPFS). The NHS cohort was established in 1976 when 121700 US female registered nurses aged 30-55 years completed a mailed questionnaire regarding their health history (Belanger et al, 1978; Colditz et al, 1997). Every 2 years, follow-up questionnaires were mailed to participants to update information on medical history, medication use, lifestyle factors, and chronic diseases. Between May 1989 and September 1990, blood samples were collected from 32826 participants. NHS cohort follow-up is $\sim 96 \%$.

The HPFS cohort was established in 1986 when 51529 male medical providers aged 45 to 70 years completed a mailed questionnaire regarding their health history (Rimm et al, 1991; Giovannucci et al, 1994). Every 2 years, follow-up questionnaires were mailed to participants to update information on medical history and medication use. Between 1993 and 1995, blood samples were also collected from 18225 participants. HPFS cohort followup is $\sim 95 \%$.

Inclusion criteria. Participants were included in this analysis if they provided a blood sample and had a pathologically confirmed diagnosis of CRC between the date of blood sampling and June 2010 for NHS and January 2010 for HPFS. To identify CRC cases, participants were asked on each follow-up questionnaire whether they had a diagnosis of CRC during the previous 2 years. When a diagnosis of CRC was reported by a participant or next of kin (if the patient was deceased at the time of contact), permission was obtained to retrieve hospital records and pathology reports. Blinded study physicians reviewed these records and recorded information on stage and important tumour characteristics. For nonrespondents, the National Death Index was used to confirm death and ascertain whether CRC contributed to death or was a secondary diagnosis. It is estimated that $96 \%$ of CRC cases were identified using these methods (Giovannucci et al, 2006).

Exclusion criteria. Patients were excluded from this analysis if they reported a diagnosis of cancer (other than non-melanoma skin cancer) or inflammatory bowel disease (IBD) before CRC diagnosis. To minimise any bias in the plasma levels of sTNF-RII associated with occult cancer, patients diagnosed with CRC within 2 years of blood collection were excluded. Based on these criteria, 319 women from the NHS cohort and 225 men from the HPFS cohort were eligible for analysis, for a total of 544 participants. All patients provided informed consent for use of their clinical data and biospecimens in the study that was approved by the institutional review board at Brigham and Women's Hospital and Harvard School of Public Health.

sTNF-RII measurement. Blood samples were collected in tubes with heparin and sent to our laboratory by overnight courier in chilled containers. Blood samples were centrifuged, aliquoted, and stored in liquid nitrogen freezers at $-160^{\circ} \mathrm{C}$. Levels of sTNF-RII were measured in a single run in a core laboratory using enzymelinked immunosorbent assay (R\&D Assays, Minneapolis, MN, USA) by blinded laboratory personnel. Blinded quality control samples were interspersed alongside test samples, and the intra-assay coefficient of variation for sTNF-RII was $6.7 \%$ (Chan et al, 2011).

The sTNF-RII is an accepted surrogate measurement for TNF- $\alpha$ because of its increased measurement stability in frozen blood samples, less diurnal variation, and its role in TNF- $\alpha$ signalling (Diez-Ruiz et al, 1995; Liu et al, 2007). Whereas plasma TNF- $\alpha$ levels tend to fluctuate, sTNF-RII levels in humans remain stable over long periods of time (Epstein et al, 2013). The stability of sTNF-RII measurements from blood samples stored for $24 \mathrm{~h}$ before processing compared with measurements obtained from samples frozen immediately after collection has been previously confirmed, with an assay intra-class correlation of 0.91 (Chan et al, 2011; Song et al, 2013).

Outcome assessment. Participants were followed from the time of diagnosis until death or June 2012 (NHS) or January 2013 (HPFS), whichever came first. Confirmation of death included reporting by family or postal authorities. Names of persistent nonresponders were searched in the National Death Index. Cause of death was assigned by blinded study physicians. More than $98 \%$ of deaths have been identified by these methods (Stampfer et al, 1984; Giovannucci et al, 2006). Overall mortality was defined as duration of time from CRC diagnosis to death from any cause. The CRCspecific mortality was defined as duration of time from diagnosis to death related to CRC. Non-CRC-specific mortality was defined as duration of time from diagnosis to death related to causes other than CRC. Patients not experiencing outcomes of interest were censored either at the time of death or at the end of the observation period defined above, if still alive.

Covariates. Data on clinically relevant covariates were extracted from questionnaires and medical records, including age at blood draw, sex, race, tumour stage at diagnosis, primary tumour site, histologic grade of differentiation, year of diagnosis (surrogate for treatment received), time between blood draw and CRC diagnosis, body mass index (BMI) at blood draw, physical activity at blood draw, and use of aspirin or non-steroidal anti-inflammatory drug (NSAID) at blood draw and post diagnosis. Post-diagnosis covariates were taken from the first questionnaire between years 1 and 4 after diagnosis to avoid confounding by the immediate postoperative period or recent chemotherapy. Regular aspirin or NSAID users were defined as those using $\geqslant 2$ tablets of regularstrength aspirin or NSAID per week. Nonregular users were defined as patients who either did not use those medications or who used $<2$ tablets per week.

Statistical analysis. We controlled for batch-to-batch variability using the method described by Rosner et al (2008). Quartiles of sTNF-RII were determined separately within each cohort. Hazard ratios (HRs) were calculated separately for HPFS and NHS and subsequently pooled for the primary analysis using a meta-analysis with a fixed effects model. Heterogeneity across cohorts was tested using the Q-statistic (DerSimonian and Laird, 1986). Overall mortality was assessed according to quartile of sTNF-RII using Kaplan-Meier curves and the log-rank test. Cox proportional hazards models were used to calculate HRs of death from all causes or death because of CRC. Models were stratified by stage and grade at diagnosis and adjusted for the potential confounding factors listed above, with the lowest quartile of sTNF-RII as the referent. The two-tailed $P$-value for the linear trend test across categories was calculated using sTNF-RII as a continuous variable in the final multivariate model (Allison, 1995).

Analyses of the relationship between sTNF-RII and mortality were also conducted within subgroups of prespecified covariates using the same model as detailed above. For continuous variables (i.e., age and physical activity), cut-points were determined by the median value. Patients with missing data for the subgroup of 
Table 1. Baseline characteristics of study cohort according to quartile of sTNF-RII $(n=544)$

\begin{tabular}{|c|c|c|c|c|}
\hline Baseline characteristics & Quartile $1(n=135)$ & Quartile $2(n=136)$ & Quartile $3(n=137)$ & Quartile $4(n=136)$ \\
\hline Mean age at blood draw, years (s.e.) & $58.5(0.70)$ & $60.9(0.64)$ & $62.5(0.63)$ & $64.3(0.68)$ \\
\hline \multicolumn{5}{|l|}{ Sex, no. (\%) } \\
\hline $\begin{array}{l}\text { Male } \\
\text { Female }\end{array}$ & $\begin{array}{l}56(41) \\
79(59)\end{array}$ & $\begin{array}{l}56(41) \\
80(59)\end{array}$ & $\begin{array}{l}57(42) \\
80(58)\end{array}$ & $\begin{array}{l}56(41) \\
80(59)\end{array}$ \\
\hline \multicolumn{5}{|l|}{ Stage, no. (\%) } \\
\hline $\begin{array}{l}\text { I } \\
\text { II } \\
\text { III } \\
\text { IV } \\
\text { Unknown/missing }\end{array}$ & $\begin{array}{l}44(33) \\
32(24) \\
26(19) \\
17(13) \\
16(12)\end{array}$ & $\begin{array}{l}36(26) \\
42(31) \\
21(15) \\
16(12) \\
21(15)\end{array}$ & $\begin{array}{l}36(26) \\
26(19) \\
31(23) \\
18(13) \\
26(19)\end{array}$ & $\begin{array}{l}31(23) \\
28(21) \\
28(21) \\
24(18) \\
25(18)\end{array}$ \\
\hline \multicolumn{5}{|l|}{ Race, no. (\%) } \\
\hline $\begin{array}{l}\text { White } \\
\text { African American } \\
\text { Other } \\
\text { Missing }\end{array}$ & $\begin{array}{l}128(95) \\
3(2) \\
1(1) \\
3(2)\end{array}$ & $\begin{array}{l}134(99) \\
1(1) \\
0(0) \\
1(1)\end{array}$ & $\begin{array}{l}131(96) \\
0(0) \\
0(0) \\
6(4)\end{array}$ & $\begin{array}{l}135(99) \\
0(0) \\
0(0) \\
1(1)\end{array}$ \\
\hline \multicolumn{5}{|l|}{ Tumour location, no. (\%) } \\
\hline $\begin{array}{l}\text { Proximal colon } \\
\text { Distal colon } \\
\text { Rectum } \\
\text { Unknown }\end{array}$ & $\begin{array}{l}1(30) \\
49(36) \\
40(30) \\
5(4)\end{array}$ & $\begin{array}{l}67(49) \\
35(26) \\
21(15) \\
13(10)\end{array}$ & $\begin{array}{l}59(43) \\
37(27) \\
27(20) \\
14(10)\end{array}$ & $\begin{array}{l}65(48) \\
31(23) \\
24(18) \\
16(12)\end{array}$ \\
\hline 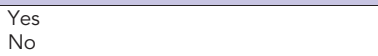 & $\begin{array}{l}44(33) \\
91(67)\end{array}$ & $\begin{array}{r}44(32) \\
92(68)\end{array}$ & $\begin{array}{l}42(31) \\
95(69)\end{array}$ & $\begin{array}{l}41(30) \\
95(70)\end{array}$ \\
\hline $\begin{array}{l}\text { Mean time between blood draw and } \\
\text { diagnosis, years (s.e.) }\end{array}$ & $8.4(0.3)$ & $9.8(0.4)$ & $9.2(0.4)$ & $8.6(0.4)$ \\
\hline \multicolumn{5}{|c|}{ Grade of differentiation, no. (\%) } \\
\hline $\begin{array}{l}\text { Well differentiated } \\
\text { Moderately differentiated } \\
\text { Poorly differentiated or undifferentiated } \\
\text { Unknown }\end{array}$ & $\begin{array}{l}22(16) \\
74(55) \\
22(16) \\
17(13)\end{array}$ & $\begin{array}{l}12(9) \\
79(58) \\
18(13) \\
27(20)\end{array}$ & $\begin{array}{l}11(8) \\
80(58) \\
17(12) \\
29(21)\end{array}$ & $\begin{array}{c}9(7) \\
73(54) \\
18(13) \\
36(26)\end{array}$ \\
\hline \multicolumn{5}{|l|}{ Year of diagnosis, no. (\%) } \\
\hline $\begin{array}{l}1990-2000 \\
2001-2010\end{array}$ & $\begin{array}{l}83(61) \\
52(39)\end{array}$ & $\begin{array}{l}61(45) \\
75(55)\end{array}$ & $\begin{array}{l}64(47) \\
73(53)\end{array}$ & $\begin{array}{l}78(57) \\
58(43)\end{array}$ \\
\hline \multicolumn{5}{|c|}{ Tobacco use at blood draw, no. (\%) } \\
\hline \multicolumn{5}{|c|}{ Regular anti-inflammatory medication use ${ }^{b}$} \\
\hline $\begin{array}{l}\text { At blood draw, no. (\%) } \\
\text { Yes } \\
\text { No } \\
\text { Missing/unknown }\end{array}$ & $\begin{array}{r}16(12) \\
106(79) \\
13(10) \\
\end{array}$ & $\begin{array}{r}17(13) \\
108(79) \\
11(8) \\
\end{array}$ & $\begin{array}{r}17(12) \\
107(78) \\
13(9) \\
\end{array}$ & $\begin{array}{r}19(14) \\
103(76) \\
14(10) \\
\end{array}$ \\
\hline $\begin{array}{l}\text { 1-4 Years after diagnosis, no. (\%) } \\
\text { Yes } \\
\text { No } \\
\text { Missing/unknown }\end{array}$ & $\begin{array}{r}13(10) \\
103(76) \\
19(14)\end{array}$ & $\begin{array}{r}18(13) \\
100(74) \\
18(13)\end{array}$ & $\begin{array}{l}20(15) \\
95(69) \\
22(16)\end{array}$ & $\begin{array}{l}13(10) \\
97(71) \\
26(19)\end{array}$ \\
\hline \multicolumn{5}{|l|}{ BMI, $\mathrm{kg} \mathrm{m}^{-2}$} \\
\hline $\begin{array}{l}\text { At blood draw, no. (\%) } \\
\text { Normal weight }(<25) \\
\text { Overweight }(25-29.9) \\
\text { Obese }(\geqslant 30)\end{array}$ & $\begin{array}{l}41(30) \\
69(51) \\
25(19)\end{array}$ & $\begin{array}{l}30(22) \\
73(54) \\
33(24)\end{array}$ & $\begin{array}{l}26(19) \\
75(55) \\
36(26)\end{array}$ & $\begin{array}{l}35(26) \\
69(51) \\
32(24)\end{array}$ \\
\hline $\begin{array}{l}\text { At diagnosis, no. }(\%) \\
\text { Normal weight }(<25) \\
\text { Overweight }(25-29.9) \\
\text { Obese }(\geqslant 30)\end{array}$ & $\begin{array}{l}31(23) \\
66(49) \\
38(28)\end{array}$ & $\begin{array}{l}30(22) \\
62(46) \\
44(32)\end{array}$ & $\begin{array}{l}32(23) \\
55(40) \\
50(37)\end{array}$ & $\begin{array}{l}35(26) \\
59(43) \\
42(31)\end{array}$ \\
\hline \multicolumn{5}{|c|}{ Median level of physical activity, MET-h per week (IQR) } \\
\hline $\begin{array}{l}\text { 1-4 Years after diagnosis } \\
\text { At blood draw }\end{array}$ & $\begin{array}{l}12.7(6.0-27.1) \\
15.4(6.0-29.0)\end{array}$ & $\begin{aligned} 8.5(5.4-21.8) \\
13.5(4.0-33.9)\end{aligned}$ & $\begin{array}{l}11.1(6.9-17.7) \\
13.9(5.9-31.1)\end{array}$ & $\begin{aligned} 8.5(4.0-16.5) \\
11.8(3.5-27.0)\end{aligned}$ \\
\hline \multicolumn{5}{|c|}{ 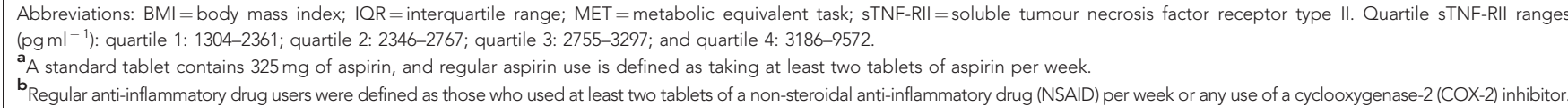 } \\
\hline
\end{tabular}


interest were excluded from the analysis. Tests of interaction between sTNF-RII and potential effect modifiers were assessed by Wald's test of cross-product terms created by multiplying the covariate of interest with sTNF-RII as a continuous variable. All analyses used SAS software, version 9.3 (SAS Institute Inc., Cary, NC, USA).

\section{RESULTS}

Among the eligible 544 patients, there were 299 deaths, with 163 deaths (55\%) because of CRC. Non-CRC causes of death included cardiovascular disease $(n=30,22 \%)$, other malignancies $(n=23$, $17 \%)$, neurologic disorders $(n=24,18 \%)$, pulmonary disorders $(n=10,7 \%)$, miscellaneous causes $(n=26,19 \%)$, and unknown reasons, typically because of the inability to confidently assign a single cause $(n=23,17 \%)$.
The median duration of follow-up of patients still alive at the end of the study was 11.5 years (range 3.9-20.5 years). The median follow-up of patients who died of any cause was 3.6 years (range 0-21.2 years). The median follow-up of those patients who died of CRC was 1.5 years (range $0-16.9$ years). The sTNF-RII levels were measured at a median of 8.7 years before CRC diagnosis (range 2-16.9 years).

Baseline characteristics according to quartile of plasma sTNFRII are shown in Table 1. Most characteristics did not differ significantly across quartiles. Patients with higher levels of sTNFRII appeared to be older, have stage IV disease at diagnosis, have proximal rather than distal colon or rectal tumours, be diagnosed earlier than 2001, and have a higher BMI at blood draw. There was no significant difference in the mean time between blood draw and diagnosis of CRC between sTNF-RII quartiles.

Kaplan-Meier curves for overall survival (Figure 1) and CRCspecific survival (Figure 2) by quartile of sTNF-RII are shown. Logrank testing demonstrated a statistically significant difference in overall survival $(P<0.0001)$ and $C R C$-specific survival $(P=0.05)$

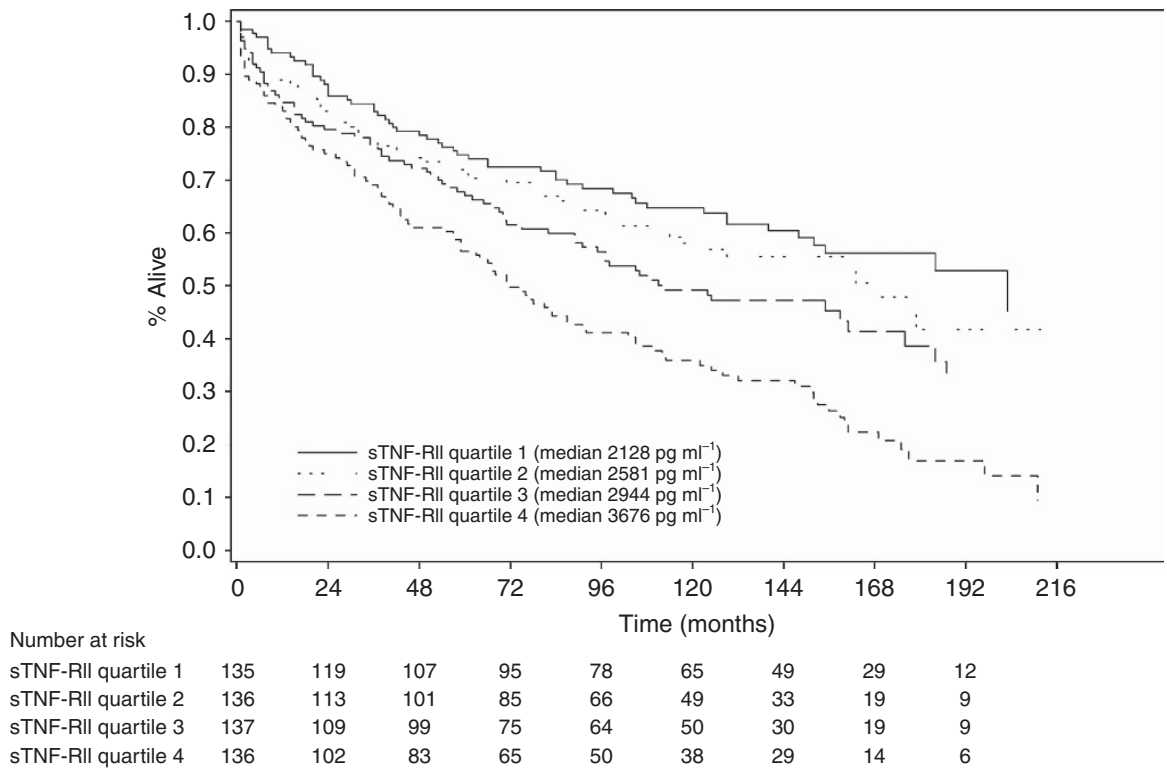

Figure 1. Overall survival by quartile of sTNF-RII.

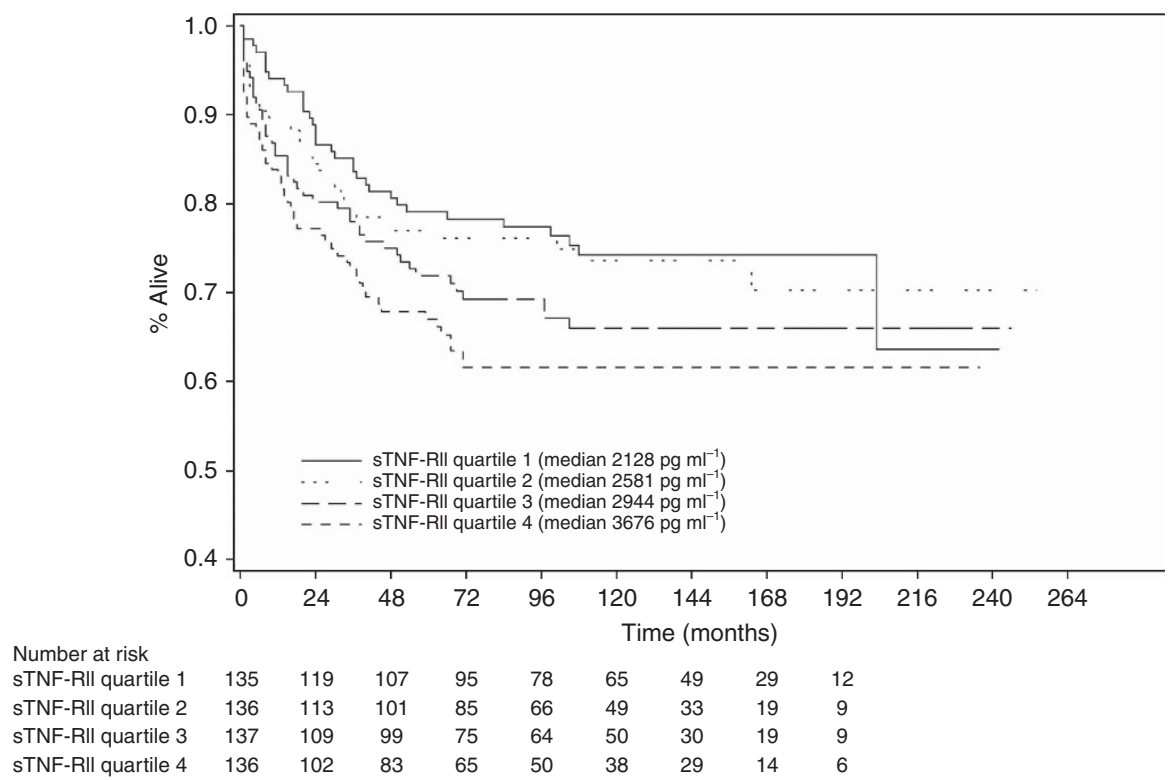

Figure 2. Colorectal cancer-specific survival by quartile of sTNF-RII. 
between quartiles of sTNF-RII. The association between prediagnosis sTNF-RII levels and overall survival in CRC patients remained significant after adjustment for potential confounders (Table 2). Patients with higher sTNF-RII plasma levels had a HR for overall mortality of 1.48 (95\% CI $1.02-2.16, P$-trend $=0.006$ ) compared with the lowest levels. Excluding stage IV patients at diagnosis, who typically have higher levels of inflammation and worse prognosis, did not appreciably alter the results $(\mathrm{HR}=1.69$, 95\% CI 1.05-2.72). In contrast, after multivariate adjustment, increasing levels of sTNF-RII were not significantly associated with increased CRC-related mortality $(\mathrm{HR}=1.23,95 \%$ CI $0.72-2.08$, $P=0.34)$. We also found a statistically significant difference in nonCRC-specific survival $(P<0.0001)$ between sTNF-RII quartiles (Kaplan-Meier curve data not shown). The significantly increased risk of non-CRC-related mortality among patients with higher sTNFRII levels persisted after multivariate adjustment $(\mathrm{HR}=1.91,95 \% \mathrm{CI}$ 1.09-3.37, $P$-trend $=0.002$; Table 2). Of note, there was no significant association between sTNF-RII and cardiovascular mortality specifically $(\mathrm{HR}=1.84,95 \% \mathrm{CI} 0.58-5.81, P$-trend $=0.15)$. When examined separately by cohort, there was no significant difference in association between sTNF-RII and overall $(P$-heterogeneity $=0.86)$, CRC-related $(P$-heterogeneity $=0.19)$, or non-CRC-related mortality $(P$-heterogeneity $=0.63$; Supplementary Table 1$)$.

To address the possibility of competing risks of non-CRCrelated death, we performed a competing risk analysis (Lunn and McNeil, 1995) and obtained similar results. Compared with patients with lowest sTNF-RII, patients with highest levels were not at statistically higher risk of CRC-related death $(\mathrm{HR}=1.29$, 95\% CI 0.78-2.12), but were at increased risk of non-CRC death $(\mathrm{HR}=2.13,95 \%$ CI $1.22-3.70)$. We performed subgroup analyses of the association of sTNF-RII with overall mortality (Figure 3). For most subgroups, the increased risk of all-cause mortality associated with higher levels of sTNF-RII was preserved. Interestingly, however, among patients who reported regular aspirin use after diagnosis, higher sTNF-RII levels were not associated with an increased risk of death (multivariate $\mathrm{HR}=0.52$, 95\% CI $0.20-1.33$ ). In contrast, nonregular aspirin users in the highest quartile of sTNF-RII showed a multivariate HR of 2.26 (95\% CI 1.23-4.04) compared with the lowest quartile $(P$ for interaction $=0.53)$.

\section{DISCUSSION}

We found that higher pre-diagnosis sTNF-RII levels were associated with an $\sim 48 \%$ increase in overall mortality compared with lower sTNF-RII levels after adjustment for potential confounding factors. Among regular users of aspirin after diagnosis, however, increasing levels of sTNF-RII were not associated with worse mortality in exploratory subgroup analyses, though the $P$ for interaction was not significant. Interestingly, we did not see a statistically significant association between higher sTNF-RII levels and CRC-specific mortality after multivariate adjustment.

Although decreased power and the strong association between sTNF-RII and non-CRC-related death are potential explanations for the nonsignificant relationship between sTNF-RII and CRCspecific mortality, it is also plausible that higher circulating sTNFRII adversely affects mortality via non-CRC-related pathways. Non-colorectal causes of death in our cohort included cardiovascular disease, other malignancies, neurologic disorders, and pulmonary disease, all of which are characterised by chronic inflammation. Moreover, several studies have demonstrated that elevated plasma sTNF-RII is associated with increased mortality in these diseases (Dobrzycka et al, 2009; Heemann et al, 2012; Schnabel et al, 2013). For example, previous analyses have clearly shown associations between sTNF-RII and cardiovascular disease, such as risk of incident coronary heart disease in healthy women (Pai et al, 2004), myocardial infarction in diabetic women in the NHS cohort (Shai et al, 2005), and cardiovascular mortality in the Framingham Heart Study (Schnabel et al, 2013). Consistent with this, we demonstrated a two-fold increase in risk of non-CRCrelated mortality among CRC patients with elevated sTNF-RII levels. We also found that higher sTNF-RII levels were associated with increased cardiovascular mortality among CRC patients, but this was not statistically significant because of the small number of patients in our study who died of cardiovascular disease $(n=30)$. These results suggest that comorbid inflammatory conditions may carry important prognostic implications for CRC patients (De Marco et al, 2000), a finding that is increasingly relevant in the

Table 2. Age-adjusted and multivariate hazard ratios for mortality by quartile of sTNF-RII $(n=544)$

\begin{tabular}{|c|c|c|c|c|c|c|c|c|c|c|c|c|c|}
\hline & \multicolumn{3}{|c|}{ Quartile 1} & \multicolumn{3}{|c|}{ Quartile 2} & \multicolumn{3}{|c|}{ Quartile 3} & \multicolumn{3}{|c|}{ Quartile 4} & \\
\hline \multicolumn{14}{|c|}{ Range of sTNF-RII (pg ml ${ }^{-1}$ ) } \\
\hline $\begin{array}{l}\text { NHS cohort }(N=319) \\
\text { HPFS cohort }(N=225)\end{array}$ & \multicolumn{3}{|c|}{$\begin{array}{l}(1459-2344) \\
(1304-2361) \\
\end{array}$} & \multicolumn{3}{|c|}{$\begin{array}{l}(2346-2752) \\
(2361-2767) \\
\end{array}$} & \multicolumn{3}{|c|}{$\begin{array}{l}(2755-3185) \\
(2771-3297)\end{array}$} & \multicolumn{3}{|c|}{$\begin{array}{l}(3186-9572) \\
(3328-5512)\end{array}$} & \\
\hline \multicolumn{14}{|l|}{ Overall mortality } \\
\hline & No. & Events & $\mathrm{HR}(95 \% \mathrm{Cl})$ & No. & Events & $\mathrm{HR}(95 \% \mathrm{Cl})$ & No. & Events & $\mathrm{HR}(95 \% \mathrm{Cl})$ & No. & Events & HR (95\% Cl) & $P$-trend ${ }^{a}$ \\
\hline $\begin{array}{l}\text { Age adjusted } \\
\text { Multivariate }^{\mathbf{c}}\end{array}$ & $\begin{array}{l}135 \\
135\end{array}$ & $\begin{array}{l}58 \\
58\end{array}$ & $\begin{array}{l}\text { Referent } \\
\text { Referent }\end{array}$ & $\begin{array}{l}136 \\
136 \\
\end{array}$ & $\begin{array}{l}62 \\
62 \\
\end{array}$ & $\begin{array}{l}.09(0.76-1.56) \\
0.93(0.63-1.38)\end{array}$ & $\begin{array}{l}137 \\
137\end{array}$ & $\begin{array}{l}76 \\
76\end{array}$ & $\begin{array}{l}1.28(0.90-1.81) \\
1.17(0.80-1.70)\end{array}$ & $\begin{array}{l}136 \\
136 \\
\end{array}$ & $\begin{array}{l}103 \\
103 \\
\end{array}$ & $\begin{array}{l}1.78(1.27-2.48) \\
1.48(1.02-2.16)\end{array}$ & $\begin{array}{l}0.0005 \\
0.006 \\
\end{array}$ \\
\hline \multicolumn{14}{|c|}{ Colorectal cancer mortality } \\
\hline & No. & Events & $\mathrm{HR}(95 \% \mathrm{Cl})$ & No. & Events & HR (95\% Cl) & No. & Events & HR (95\% Cl) & No. & Events & HR (95\% Cl) & $P$-trend \\
\hline $\begin{array}{l}\text { Age adjusted } \\
\text { Multivariate }^{\mathbf{c}}\end{array}$ & $\begin{array}{l}135 \\
135\end{array}$ & $\begin{array}{l}34 \\
34 \\
\end{array}$ & $\begin{array}{l}\text { Referent } \\
\text { Referent }\end{array}$ & $\begin{array}{l}136 \\
136 \\
\end{array}$ & $\begin{array}{l}35 \\
35\end{array}$ & $\begin{array}{l}1.04(0.64-1.70) \\
1.05(0.62-1.78)\end{array}$ & $\begin{array}{l}137 \\
137\end{array}$ & $\begin{array}{l}44 \\
44\end{array}$ & $\begin{array}{l}1.25(0.77-2.01) \\
1.25(0.75-2.10)\end{array}$ & $\begin{array}{l}136 \\
136 \\
\end{array}$ & $\begin{array}{l}50 \\
50 \\
\end{array}$ & $\begin{array}{l}1.49(0.95-2.35) \\
1.23(0.72-2.08)\end{array}$ & $\begin{array}{l}0.12 \\
0.34\end{array}$ \\
\hline \multicolumn{14}{|c|}{ Non-colorectal cancer-specific mortality } \\
\hline & No. & Events & HR $(95 \% \mathrm{Cl})$ & No. & Events & HR (95\% Cl) & No. & Events & HR (95\% Cl) & No. & Events & HR (95\% Cl) & $P$-trend ${ }^{a}$ \\
\hline $\begin{array}{l}\text { Age adjusted } \\
\text { Multivariate }^{\mathrm{c}}\end{array}$ & $\begin{array}{l}135 \\
135 \\
\end{array}$ & $\begin{array}{l}24 \\
24 \\
\end{array}$ & $\begin{array}{l}\text { Referent } \\
\text { Referent }\end{array}$ & $\begin{array}{l}136 \\
136 \\
\end{array}$ & $\begin{array}{l}27 \\
27 \\
\end{array}$ & $\begin{array}{l}1.12(0.63-2.00) \\
0.84(0.45-1.55)\end{array}$ & $\begin{array}{l}137 \\
137\end{array}$ & $\begin{array}{l}32 \\
32\end{array}$ & $\begin{array}{l}1.29(0.75-2.21) \\
1.00(0.55-1.83)\end{array}$ & $\begin{array}{l}136 \\
136\end{array}$ & $\begin{array}{l}53 \\
53\end{array}$ & $\begin{array}{l}2.18(1.31-3.63) \\
1.91(1.09-3.37)\end{array}$ & $\begin{array}{l}0.0002 \\
0.002\end{array}$ \\
\hline \multicolumn{14}{|c|}{ 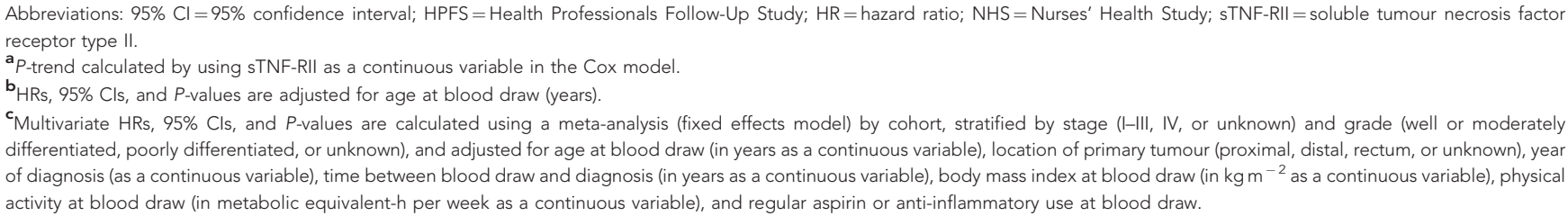 } \\
\hline
\end{tabular}




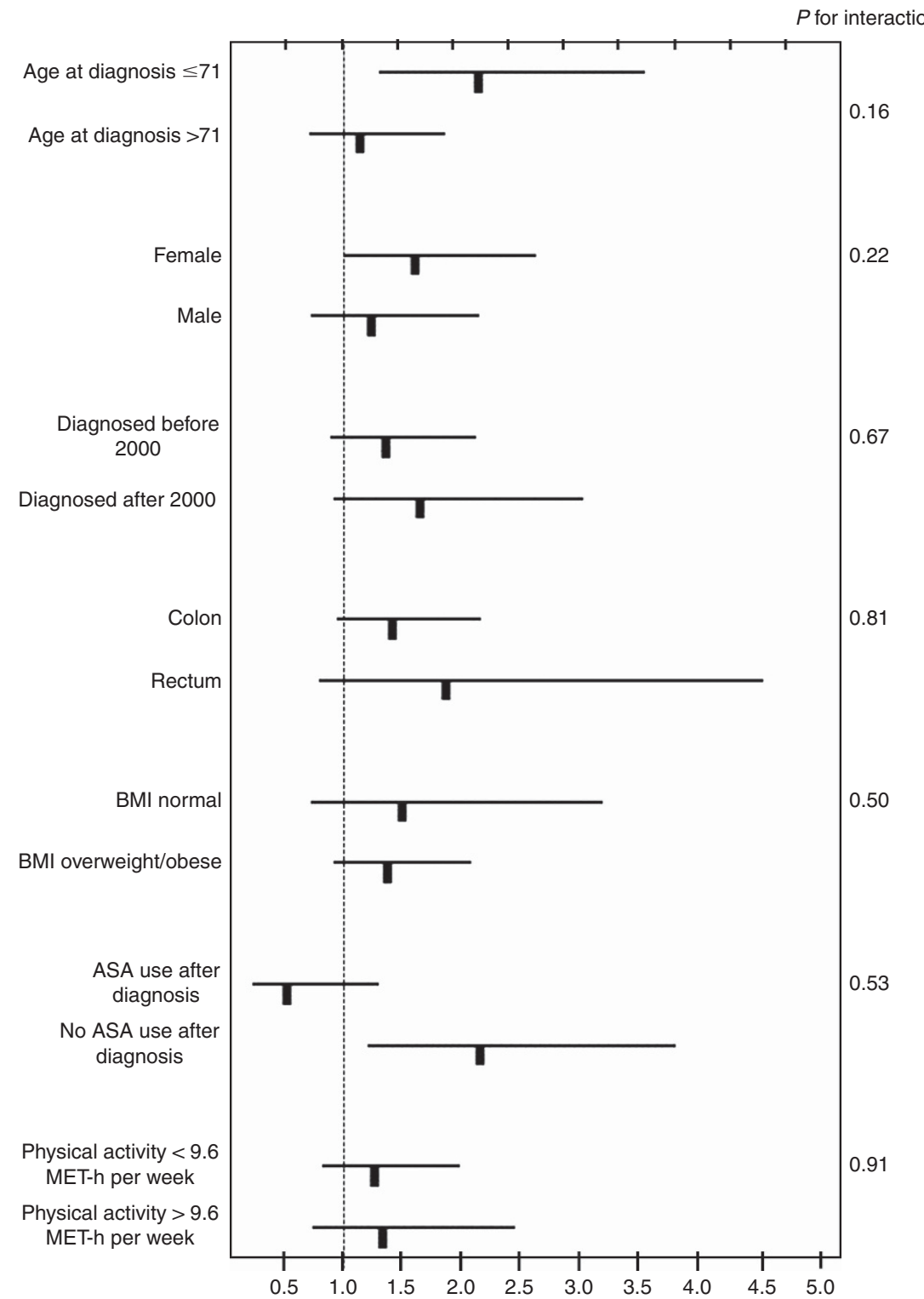

Figure 3. Relationship between sTNF-RII and overall mortality in prespecified patient subgroups. Multivariate hazard ratios (HRs) and 95\% confidence intervals (Cls) for overall mortality across subgroups of various factors, comparing CRC patients in the highest quartile of plasma sTNFRIl levels with patients in the lowest sTNF-RIl quartile. Subgroups include age at diagnosis (less than or equal to cohort median diagnosis age of 71 years, greater than cohort median diagnosis age), sex (male, female), year of diagnosis (before and including the year 2000, after the year 2000), tumour location at diagnosis (colon, rectum), BMI ( $\mathrm{kg} \mathrm{m}^{-2}$ ) at diagnosis (normal weight, overweight, or obese), regular aspirin (ASA) use 1-4 years after diagnosis (yes, no), and physical activity 1-4 years after diagnosis (less than or equal to cohort median physical activity of 9.6 metabolic equivalent task (MET)-h per week, greater than median physical activity).

context of the longer life expectancy of CRC patients in recent years.

Interestingly, our study found that higher sTNF-RII levels were not associated with worse outcome among patients who reported regular aspirin use, although the $P$-value for interaction between sTNF-RII and aspirin was not significant, possibly because of reduced power in exploratory subgroup analyses. Ample clinical data (Algra and Rothwell, 2012) suggest that initiation of aspirin after CRC diagnosis may be beneficial in reducing mortality, particularly among older patients (Lai and Liao, 2013) and COX-2overexpressing (Chan et al, 2009) or PIK3CA-mutated tumours (Liao et al, 2012; Langley and Rothwell, 2013). Moreover, treatment with COX inhibitors leads to inhibition of TNF- $\alpha$ induced COX-2 expression and decreased proliferation of CRC cells (Ricchi et al, 1997; Paik et al, 2000), thus lending biologic plausibility to our findings. Currently, a large, randomised
Intergroup study, CALGB/Alliance 80702, is testing the efficacy of celecoxib, a selective COX-2 inhibitor, for preventing disease recurrence in stage III colon cancer patients, and future studies should investigate the impact of these medications on TNF- $\alpha$ signalling and prognosis.

The strengths of our study include its prospective design, and use of two established cohorts with high rates of long-term followup for measurement of confounders and mortality end points. Moreover, NHS and HPFS participants are motivated medical professionals who provide accurate information about potential confounders and outcomes.

A potential study limitation is that only one measurement of sTNF-RII was drawn before diagnosis; however, previous studies have demonstrated that sTNF-RII levels stay fairly constant over time (Epstein et al, 2013). Higher sTNF-RII levels may also be a consequence of cancer, rather than a factor in the causative 
pathway, or reflect other poor prognostic factors. However, we adjusted our analysis for potential risk factors for CRC mortality, and attempted to control for reverse causation by excluding patients diagnosed with CRC within 2 years of blood draw. Moreover, excluding patients with stage IV disease at diagnosis (who often have the highest sTNF-RII levels and mortality rates) from the analysis did not significantly alter our results. Although NHS and HPFS cohort questionnaire data are extensive, information about treatment is limited, and hence we adjusted the analysis for year of diagnosis as a surrogate for treatment. Another limitation is the racial homogeneity of the NHS and HPFS cohorts ( $>90 \%$ white), possibly reducing the generalisability of our findings, although it is unlikely that the underlying biological pathways of inflammation differ by race.

In conclusion, pre-diagnosis plasma levels of sTNF-RII among CRC patients are significantly associated with increased overall mortality. Future studies should continue to explore the role of inflammatory signalling and methods of reducing inflammation in patients with colorectal cancer.

\section{ACKNOWLEDGEMENTS}

We thank the participants and staff of the Nurses' Health Study and the Health Professionals Follow-Up Study for their valuable contributions as well as the following state cancer registries for their help: AL, AZ, AR, CA, CO, CT, DE, FL, GA, ID, IL, IN, IA, KY, LA, ME, MD, MA, MI, NE, NH, NJ, NY, NC, ND, OH, OK, OR, PA, RI, SC, TN, TX, VA, WA, and WY. We assume full responsibility for analyses and interpretation of these data. This work was supported by the National Cancer Institute at the National Institutes of Health (K07 CA148894 to KN; R01 CA137178 to ATC; K24 DK098311 to ATC; R01 CA151993 and R35 CA197735 to SO; P50 CA127003 to CSF), the Damon Runyon Cancer Research Foundation (to ATC), the American Society of Clinical Oncology (ASCO) Career Development Award (to KN), the Entertainment Industry Foundation's National Colorectal Cancer Research Alliance (NCCRA), and the Dana Farber Cancer Institute Gift Funds from the Janock Fellowship and Herndon Fellowship (to SMS). Other funding sources include UM1 CA186107 (NHS cohort infrastructure grant), P01 CA87969 (NHS program project grant), R01 CA49449 (NHS blood grant), UM1 CA167552 (HPFS infrastructure grant), and P01 CA 55075 (HPFS program project grant).The sponsors did not participate in the design and conduct of the study; collection, analysis, and interpretation of the data; preparation, review, or approval of the manuscript; or decision to submit the article for publication. The contents of this article are solely the responsibility of the authors and do not necessarily represent the official views of the National Cancer Institute or the National Institutes of Health, ASCO, The Conquer Cancer Foundation, the Damon Runyon Cancer Research Foundation, or the NCCRA.

\section{CONFLICT OF INTEREST}

The authors declare no conflict of interest.

\section{REFERENCES}

Algra AM, Rothwell PM (2012) Effects of regular aspirin on long-term cancer incidence and metastasis: a systematic comparison of evidence from observational studies vs randomised trials. Lancet Oncol 13(5): 518-527.

Allison PD (1995) Survival Analysis Using SAS: A Practical Guide. pp 111-185. SAS Institute: Cary, NC, USA.
Arber N, Eagle CJ, Spicak J, Racz I, Dite P, Hajer J, Zavoral M, Lechuga MJ, Gerletti P, Tang J, Rosenstein RB, Macdonald K, Bhadra P, Fowler R, Wittes J, Zauber AG, Solomon SD, Levin B. PreSAP Trial Investigators (2006) Celecoxib for the prevention of colorectal adenomatous polyps. $N$ Engl J Med 355(9): 885-895.

Belanger CF, Hennekens CH, Rosner B, Speizer FE (1978) The nurses' health study. Am J Nurs 78(6): 1039-1040.

Bernstein CN, Blanchard JF, Kliewer E, Wajda A (2001) Cancer risk in patients with inflammatory bowel disease: a population-based study. Cancer 91(4): 854-862.

Bertagnolli MM, Eagle CJ, Zauber AG, Redston M, Solomon SD, Kim K, Tang J, Rosenstein RB, Wittes J, Corle D, Hess TM, Woloj GM, Boisserie F, Anderson WF, Viner JL, Bagheri D, Burn J, Chung DC, Dewar T, Foley TR, Hoffman N, Macrae F, Pruitt RE, Saltzman JR, Salzberg B, Sylwestrowicz T, Gordon GB, Hawk ET. APC Study Investigators (2006) Celecoxib for the prevention of sporadic colorectal adenomas. N Engl J Med 355(9): 873-884.

Chan AT, Ogino S, Fuchs CS (2009) Aspirin use and survival after diagnosis of colorectal cancer. JAMA 302(6): 649-658.

Chan AT, Ogino S, Giovannucci EL, Fuchs CS (2011) Inflammatory markers are associated with risk of colorectal cancer and chemopreventive response to anti-inflammatory drugs. Gastroenterology 140(3): 799-808, quiz e11.

Colditz GA, Manson JE, Hankinson SE (1997) The Nurses' Health Study: 20 -year contribution to the understanding of health among women. $J$ Womens Health 6(1): 49-62.

De Marco MF, Janssen-Heijnen ML, van der Heijden LH, Coebergh JW (2000) Comorbidity and colorectal cancer according to subsite and stage: a population-based study. Eur J Cancer 36(1): 95-99.

DerSimonian R, Laird N (1986) Meta-analysis in clinical trials. Control Clin Trials 7(3): 177-188.

Diez-Ruiz A, Tilz GP, Zangerle R, Baier-Bitterlich G, Wachter H, Fuchs D (1995) Soluble receptors for tumour necrosis factor in clinical laboratory diagnosis. Eur J Haematol 54(1): 1-8.

Dobrzycka B, Terlikowski SJ, Kowalczuk O, Kinalski M (2009) Circulating levels of TNF-alpha and its soluble receptors in the plasma of patients with epithelial ovarian cancer. Eur Cytokine Netw 20(3): 131-134.

Epstein MM, Breen EC, Magpantay L, Detels R, Lepone L, Penugonda S, Bream JH, Jacobson LP, Martinez-Maza O, Birmann BM (2013) Temporal stability of serum concentrations of cytokines and soluble receptors measured across two years in low-risk HIV-seronegative men. Cancer Epidemiol Biomarkers Prev 22(11): 2009-2015.

Faustman D, Davis M (2010) TNF receptor 2 pathway: drug target for autoimmune diseases. Nat Rev Drug Discov 9(6): 482-493.

Giovannucci E, Liu Y, Rimm EB, Hollis BW, Fuchs CS, Stampfer MJ, Willett WC (2006) Prospective study of predictors of vitamin D status and cancer incidence and mortality in men. J Natl Cancer Inst 98(7): 451-459.

Giovannucci E, Rimm EB, Stampfer MJ, Colditz GA, Ascherio A, Willett WC (1994) Intake of fat, meat, and fiber in relation to risk of colon cancer in men. Cancer Res 54(9): 2390-2397.

Hamilton KE, Simmons JG, Ding S, Van Landeghem L, Lund PK (2011) Cytokine induction of tumor necrosis factor receptor 2 is mediated by STAT3 in colon cancer cells. Mol Cancer Res 9(12): 1718-1731.

Heemann C, Kreuz M, Stoller I, Schoof N, von Bonin F, Ziepert M, Loffler M, Jung W, Pfreundschuh M, Trumper L, Kube D (2012) Circulating levels of TNF receptor II are prognostic for patients with peripheral T-cell nonHodgkin lymphoma. Clin Cancer Res 18(13): 3637-3647.

Kant P, Hull MA (2011) Excess body weight and obesity-the link with gastrointestinal and hepatobiliary cancer. Nat Rev Gastroenterol Hepatol 8(4): 224-238.

Lai SW, Liao KF (2013) Aspirin use after diagnosis improves survival in older adults with colon cancer. J Am Geriatr Soc 61(5): 843-844.

Langley RE, Rothwell PM (2013) Potential biomarker for aspirin use in colorectal cancer therapy. Nat Rev Clin Oncol 10(1): 8-10.

Liao X, Lochhead P, Nishihara R, Morikawa T, Kuchiba A, Yamauchi M, Imamura Y, Qian ZR, Baba Y, Shima K, Sun R, Nosho K, Meyerhardt JA, Giovannucci E, Fuchs CS, Chan AT, Ogino S (2012) Aspirin use, tumor PIK3CA mutation, and colorectal-cancer survival. N Engl J Med 367(17): 1596-1606.

Liu S, Tinker L, Song Y, Rifai N, Bonds DE, Cook NR, Heiss G, Howard BV, Hotamisligil GS, Hu FB, Kuller LH, Manson JE (2007) A prospective study of inflammatory cytokines and diabetes mellitus in a multiethnic cohort of postmenopausal women. Arch Intern Med 167(15): 1676-1685. 
Lunn M, McNeil D (1995) Applying Cox regression to competing risks. Biometrics 51(2): 524-532.

Matsuyama R, Togo S, Shimizu D, Momiyama N, Ishikawa T, Ichikawa Y, Endo I, Kunisaki C, Suzuki H, Hayasizaki Y, Shimada H (2006) Predicting 5-fluorouracil chemosensitivity of liver metastases from colorectal cancer using primary tumor specimens: three-gene expression model predicts clinical response. Int J Cancer 119(2): 406-413.

Pai JK, Pischon T, Ma J, Manson JE, Hankinson SE, Joshipura K, Curhan GC, Rifai N, Cannuscio CC, Stampfer MJ, Rimm EB (2004) Inflammatory markers and the risk of coronary heart disease in men and women. $N$ Engl $J$ Med 351(25): 2599-2610.

Paik JH, Ju JH, Lee JY, Boudreau MD, Hwang DH (2000) Two opposing effects of non-steroidal anti-inflammatory drugs on the expression of the inducible cyclooxygenase. Mediation through different signaling pathways. J Biol Chem 275(36): 28173-28179.

Popivanova BK, Kitamura K, Wu Y, Kondo T, Kagaya T, Kaneko S, Oshima M, Fujii C, Mukaida N (2008) Blocking TNF-alpha in mice reduces colorectal carcinogenesis associated with chronic colitis. J Clin Invest 118(2): 560-570.

Ricchi P, Pignata S, Di Popolo A, Memoli A, Apicella A, Zarrilli R, Acquaviva AM (1997) Effect of aspirin on cell proliferation and differentiation of colon adenocarcinoma Caco-2 cells. Int J Cancer 73(6): 880-884.

Rimm EB, Giovannucci EL, Willett WC, Colditz GA, Ascherio A, Rosner B, Stampfer MJ (1991) Prospective study of alcohol consumption and risk of coronary disease in men. Lancet 338(8765): 464-468.

Rosner B, Cook N, Portman R, Daniels S, Falkner B (2008) Determination of blood pressure percentiles in normal-weight children: some methodological issues. Am J Epidemiol 167(6): 653-666.

Sandler RS, Halabi S, Baron JA, Budinger S, Paskett E, Keresztes R, Petrelli N, Pipas JM, Karp DD, Loprinzi CL, Steinbach G, Schilsky R (2003) A randomized trial of aspirin to prevent colorectal adenomas in patients with previous colorectal cancer. N Engl J Med 348(10): 883-890.

Schnabel RB, Yin X, Larson MG, Yamamoto JF, Fontes JD, Kathiresan S, Rong J, Levy D, Keaney Jr JF, Wang TJ, Murabito JM, Vasan RS, Benjamin EJ (2013) Multiple inflammatory biomarkers in relation to cardiovascular events and mortality in the community. Arterioscler Thromb Vasc Biol 33(7): 1728-1733.

Setia S, Nehru B, Sanyal SN (2013) Activation of NF-kappaB: bridging the gap between inflammation and cancer in colitis-mediated colon carcinogenesis. Biomed Pharmacother 68(1): 119-128.

Shai I, Schulze MB, Manson JE, Rexrode KM, Stampfer MJ, Mantzoros C, Hu FB (2005) A prospective study of soluble tumor necrosis factor-alpha receptor II (sTNF-RII) and risk of coronary heart disease among women with type 2 diabetes. Diabetes Care 28(6): 1376-1382.

Song M, Wu K, Ogino S, Fuchs CS, Giovannucci EL, Chan AT (2013) A prospective study of plasma inflammatory markers and risk of colorectal cancer in men. Br J Cancer 108(9): 1891-1898.

Spoettl T, Hausmann M, Klebl F, Dirmeier A, Klump B, Hoffmann J, Herfarth H, Timmer A, Rogler G (2007) Serum soluble TNF receptor I and II levels correlate with disease activity in IBD patients. Inflamm Bowel Dis 13(6): 727-732.

Stampfer MJ, Willett WC, Speizer FE, Dysert DC, Lipnick R, Rosner B, Hennekens CH (1984) Test of the National Death Index. Am J Epidemiol 119(5): 837-839.

Steinbach G, Lynch PM, Phillips RK, Wallace MH, Hawk E, Gordon GB, Wakabayashi N, Saunders B, Shen Y, Fujimura T, Su LK, Levin B, Godio L, Patterson S, Rodriguez-Bigas MA, Jester SL, King KL, Schumacher M, Abbruzzese J, DuBois RN, Hittelman WN, Zimmerman S, Sherman JW, Kelloff G (2000) The effect of celecoxib, a cyclooxygenase-2 inhibitor, in familial adenomatous polyposis. N Engl J Med 342(26): 1946-1952.

Zhu M, Zhu Y, Lance P (2013) TNFalpha-activated stromal COX-2 signalling promotes proliferative and invasive potential of colon cancer epithelial cells. Cell Prolif 46(4): 374-381.

This work is published under the standard license to publish agreement. After 12 months the work will become freely available and the license terms will switch to a Creative Commons AttributionNonCommercial-Share Alike 4.0 Unported License.

Supplementary Information accompanies this paper on British Journal of Cancer website (http://www.nature.com/bjc) 